\title{
DAMPAK MANAJEMEN LABA TERHADAP PERENCANAAN PAJAK DAN PERSISTENSI LABA
}

\author{
Nila Trisna Syanthi \\ nila.trisna.syanthi@gmail.com \\ Made Sudarma \\ Erwin Saraswati \\ Universitas Brawijaya
}

\begin{abstract}
This study aims to examine the effect of earnings management on tax planning and earnings persistence using firm size as a control variable. The analytical method used is panel data regression using secondary data from the Indonesia Stock Exchange. The sample consists of 40 manufacturing firms in period of 2006-2010. The test results found that both real earnings management and accrual earnings management increase earnings persistence, while tax planning does not affect earnings persistence. Firms do real earnings management through the manipulation of sales and reduction of discretionary expenses to influence earnings persistence, while overproduction does not affect earnings persistence. In addition, the firms do not perform earnings management in tax planning. The firms that perform earnings management would have more persistent earnings than firms that do not perform earnings management. The larger the firm size, the more persistent the earnings. This study supports the agency theory which explains that earnings management is done by signaling motivation.
\end{abstract}

Keywords: Earnings management, tax planning, earnings persistence.

\begin{abstract}
ABSTRAK
Penelitian ini bertujuan untuk menguji pengaruh manajemen laba terhadap perencanaan pajak dan persistensi laba dengan menggunakan ukuran perusahaan sebagai variabel kontrol. Metode analisis yang digunakan adalah regresi data panel dengan menggunakan data sekunder dari Bursa Efek Indonesia. Sampel terdiri atas 40 perusahaan manufaktur selama periode 2006-2010. Berdasarkan hasil pengujian ditemukan bahwa baik manajemen laba riil maupun manajemen laba akrual meningkatkan persistensi laba, sedangkan perencanaan pajak tidak mempengaruhi persistensi laba. Perusahaan melakukan manajemen laba riil melalui manipulasi penjualan dan pengurangan beban diskresi tunai untuk mempengaruhi persistensi laba, sedangkan produksi barang secara berlebihan terbukti tidak mempengaruhi persistensi laba. Selain itu, perusahaan terbukti tidak melakukan manajemen laba dalam melakukan perencanaan pajak. Perusahaan yang melakukan manajemen laba akan memiliki laba yang lebih persisten dibandingkan dengan perusahaan yang tidak melakukan manajemen laba. Semakin besar ukuran perusahaan, semakin persisten laba perusahaan. Penelitian ini mendukung teori keagenan yang menjelaskan bahwa manajemen laba dilakukan dengan motivasi signaling.
\end{abstract}

Kata kunci: Manajemen laba, perencanaan pajak, persistensi laba.

\section{PENDAHULUAN}

Fenomena penggelapan pajak (tax evasion) seperti kasus penggelapan pajak yang dilakukan oleh Grup Asian Agri, Grup Bakrie, Makindo, dan Grup Ramayana (Mathari et al., 2010) merupakan salah satu isu penting yang sering dibahas di Indo- nesia saat ini. Fenomena ini muncul akibat adanya perbedaan kepentingan antara perusahaan sebagai wajib pajak dengan pemerintah sebagai pemungut pajak, sehingga mendorong wajib pajak untuk cenderung melakukan minimalisasi beban pajak baik secara legal maupun illegal. Wajib pajak 
menginginkan pembayaran pajak seminimal mungkin, karena beban pajak yang besar akan menurunkan laba bersih setelah pajak (earnings after tax), tingkat pengembalian (rate of return), dan arus kas (cash flows). Sebaliknya, pemerintah menginginkan penerimaan pajak yang relatif besar guna membiayai pengeluaran negara.

Perencanaan pajak (tax planning) merupakan salah satu fungsi dari manajemen pajak yang digunakan untuk mengestimasi jumlah pajak yang akan dibayar dan hal-hal yang dapat dilakukan untuk menghindari pajak. Isu dalam penelitian ini adalah adanya motif perencanaan pajak yang digunakan perusahaan untuk melakukan penghematan pajak yang tidak sesuai dengan peraturan perpajakan. Terungkapnya kasus penggelapan pajak yang dilakukan oleh beberapa perusahaan di Indonesia membuktikan bahwa perusahaan melakukan perencanaan pajak yang agresif dengan cara melakukan pembiayaan fiktif, transaksi ekspor fiktif, dan transfer pricing untuk merekayasa omzet penjualan.

Perencanaan pajak terkait dengan pelaporan laba perusahaan. Laba yang tinggi akan menyebabkan beban pajak perusahaan juga tinggi. Oleh karena itu, manajemen perusahaan akan menggunakan berbagai teknik manajemen laba untuk mencapai target laba (Zang, 2006). Perencanaan pajak dan manajemen laba terkait satu sama lain, karena sama-sama bertujuan untuk mencapai target laba dengan merekayasa angka laba dalam laporan keuangan. Berbagai tindakan yang dilakukan oleh perusahaan untuk menggelapkan pajak menunjukkan bahwa perencanaan pajak dilakukan dengan memanipulasi aktivitas operasi perusahaan (real earnings management).

Saat ini, manajemen laba berbasis aktivitas riil telah banyak mendapat perhatian dari para peneliti (Graham et al., 2005; Gunny, 2005; Zang, 2006; Roychowdhury, 2006; Yu, 2008; Cohen dan Zarowin, 2008; Gunny, 2009; Cohen dan Zarowin, 2010; Ratmono, 2010; Subekti et al., 2010; Ibrahim et al., 2011; serta Lee dan Swenson, 2011), karena manajer telah beralih dari manajemen laba berbasis akrual ke manajemen laba riil untuk menghindari deteksi yang dilakukan auditor dan regulator (Graham et al., 2005; Cohen dan Zarowin, 2008; dan Ibrahim et al., 2011). Namun, untuk menguji pengaruh manajemen laba secara keseluruhan, peneliti tidak dapat meneliti satu teknik manajemen laba saja, karena adanya hubungan substitusi antara manajemen laba riil dengan manajemen laba akrual. Ketika manipulasi aktivitas riil tinggi, maka manajer akan mengurangi jumlah manajemen laba akrual, dan sebaliknya (Zang, 2006).

Manajemen laba riil cenderung dilakukan sebelum tahun fiskal berakhir, sedangkan manajemen laba akrual cenderung dilakukan setelah tahun fiskal berakhir (Zang, 2006 dan Gunny, 2009). Kebijakan akrual akan menghasilkan kekaburan laba yang mengurangi kualitas laba dan menyebabkan rendahnya persistensi laba (Sunarto, 2010). Namun, manajemen laba riil juga dapat menyebabkan rendahnya persistensi laba, karena manajemen laba dapat dilakukan perusahaan melalui manipulasi akrual murni dan manipulasi aktivitas riil (Scott, 2009:403).

Manajemen laba maupun perencanaan pajak sama-sama memiliki potensi untuk mempengaruhi laba akuntansi dan laba fiskal (Chen et al., 2007). Manajemen laba akan meningkatkan laba akuntansi, sehingga laba fiskal juga akan meningkat. Sebaliknya, perencanaan pajak akan mengurangi laba fiskal yang juga akan mengurangi laba akuntansi. Perusahaan yang melakukan manajemen laba dan perencanaan pajak akan memiliki laba akuntansi dan laba fiskal yang berbeda dalam jumlah yang relatif besar (Hanlon, 2005). Oleh karena itu, dilakukan peningkatan kesesuaian antara laba akuntansi dan laba fiskal dengan satu pengukuran.

Peningkatan kesesuaian antara laba akuntansi dan laba fiskal mengurangi jumlah perencanaan pajak perusahaan, tetapi di sisi lain mengurangi kandungan informasi laba akuntansi, karena perusahaan akan 
cenderung melakukan manajemen laba yang tidak diikuti oleh peningkatan laba kena pajak (Hanlon dan Shevlin, 2005; Hanlon et al., 2006; dan Hanlon et al., 2007; Ayers et al., 2008; serta Atwood et al., 2010). Penyesuaian antara laba akuntansi dan laba fiskal menyebabkan laba akuntansi perusahaan memiliki persistensi yang lebih rendah untuk periode satu tahun ke depan. Selain itu, perusahaan yang memiliki laba fiskal lebih besar dari laba akuntansi (large negative book-tax differences) memiliki persistensi komponen akrual yang lebih tinggi dibandingkan dengan arus kas (Wijayanti, 2006).

Penelitian ini menggabungkan penelitian Chen et al.(2007) dan Atwood et al. (2010) dengan menguji dampak manajemen laba terhadap perencanaan pajak, serta bagaimana pengaruh manajemen laba dan perencanaan pajak terhadap persistensi laba. Persistensi laba merupakan komponen dari karakteristik kualitatif relevansi yaitu predictive value, sehingga persistensi laba sering digunakan sebagai pertimbangan kualitas laba (Jonas dan Blanchet, 2000). Peneliti tertarik untuk melakukan penelitian ini, karena adanya perbedaan hasil penelitian terdahulu mengenai hubungan antara manajemen laba dengan perencanaan pajak (Chen et al., 2007; Hanlon dan Shevlin, 2005; Hanlon et al., 2006; dan Hanlon et al., 2007; Ayers et al., 2008; serta Atwood et al., 2010).

Adapun perbedaan penelitian ini dengan penelitian terdahulu adalah penelitian Chen et al. (2007) dan Atwood et al. (2010) dilakukan berdasarkan peraturan pajak di Amerika Serikat, sedangkan penelitian ini dilakukan di Indonesia yang memiliki peraturan pajak yang berbeda. Di Indonesia, belum ada definisi yang jelas mengenai tax planning, aggresive tax planning, acceptable tax avoidance, dan unacceptable tax avoidance, sehingga menimbulkan penafsiran yang berbeda antara wajib pajak dengan aparat pajak. Sebaliknya, Amerika Serikat memiliki peraturan perundang-undangan perpajakan untuk mencegah penghindaran pajak berupa Specific Anti Avoidance Rule (SAAR) dan General Anti Avoidance Rule (GAAR) guna memberikan kepastian hukum bagi wajib pajak maupun pemerintah (Darussalam dan Septriadi, 2009). Selain itu, penelitian Chen et al. (2007) dan Atwood et al. (2010) hanya fokus pada manajemen laba akrual, sedangkan penelitian ini menguji kedua teknik manajemen laba, baik manajemen laba akrual maupun manajemen laba riil. Penelitian ini menggunakan teori keagenan untuk menjelaskan manajemen laba perusahaan.

Penelitian ini memiliki keunikan dibandingkan dengan penelitian lainnya dalam hal pengukuran variabel perencanaan pajak. Perencanaan pajak diukur dengan menggunakan proksi cash effective tax rate yang telah digunakan oleh beberapa peneliti di Amerika Serikat. Sejauh ini, peneliti belum menemukan adanya penelitian di Indonesia yang menggunakan proksi yang sama.

Penelitian ini memberi kontribusi terhadap literatur manajemen laba khususnya kaitan antara manajemen laba dengan perencanaan pajak. Teori keagenan mengelompokkan motivasi manajemen akrual dalam dua kategori, yaitu opportunistic dan signaling (Beaver, 2002). Perilaku manajemen laba yang dibuktikan dalam peneliti an ini mendukung motivasi signaling, karena manajemen laba terbukti dilakukan perusahaan untuk memberi sinyal mengenai kemakmuran pemegang saham.

Penelitian ini memberi kontribusi pada literatur kualitas laba (earnings quality) dengan membuktikan adanya keterkaitan antara dua teknik manajemen laba, yakni manajemen laba riil dan akrual dengan perencanaan pajak dan persistensi laba yang belum dilakukan oleh peneliti sebelum nya (Hanlon, 2005; Chen et al.,2007; dan Atwood et al., 2010). Persistensi laba adalah salah satu bagian penting dari kualitas laba. Dalam melakukan analisis terhadap laporan keuangan, para peneliti tertarik untuk mengetahui bagaimana laba saat ini atau laba di masa lalu serta komponen-komponen laba digunakan untuk memprediksi 
laba dan arus kas di masa depan. Hasil penelitian ini memberi bukti empiris bahwa manajemen perusahaan cenderung melakukan manajemen laba untuk memberi sinyal kepada pemegang saham mengenai kinerja perusahaan yang lebih baik di masa depan. Dengan kata lain, laba sekarang perusahaan yang melakukan manajemen laba dapat digunakan untuk memprediksi laba dan arus kas di masa depan.

\section{LANDASAN TEORETIS}

\section{Teori Keagenan (Agency Theory) dan Manajemen Laba (Earnings Management)}

Teori keagenan (agency theory) mengimplikasi adanya asimetri informasi antara manajer sebagai agen dan pemilik (pemegang saham) sebagai prinsipal. Asimetri informasi muncul ketika manajer lebih mengetahui informasi internal dan prospek perusahaan di masa yang akan datang dibandingkan pemegang saham dan stakeholder lainnya. Jika dikaitkan dengan peningkatan nilai perusahaan, ketika terdapat asimetri informasi, manajer dapat memberi sinyal mengenai kondisi perusahaan kepada investor guna memaksimalkan nilai saham perusahaan. Sinyal yang diberikan dapat dilakukan melalui pengungkapan (disclosure) informasi akuntansi. Namun, adanya kecenderungan manajer untuk mencari keuntungan sendiri (moral hazard) dan tingkat asimetri informasi yang tinggi, ditambah motif-motif tertentu, memperbesar kemungkinan manajemen memanfaatkan pos-pos akrual guna menyajikan laba yang sesuai dengan kepentingan manajemen yang mungkin tidak sesuai dengan kepentingan prinsipal, seperti pemilik, pemegang saham, atau pemberi pinjaman.

Teori keagenan mengelompokkan motivasi manajemen laba akrual dalam 2 kategori: opportunistic dan signaling (Beaver, 2002). Pada motivasi opportunistic, manajemen melalui kebijakan akuntansi yang agresif melaporkan angka laba lebih tinggi daripada laba yang sesungguhnya. Apabila laba yang dilaporkan tidak dapat menggambarkan laba yang sesungguhnya, maka laporan laba mengarah pada overstate earnings yang mengakibatkan laba menjadi kabur (opaque). Motivasi opportunistic yang dilakukan oleh manajemen berhubungan dengan kompensasi berdasarkan kontrak yang disepakati dengan pihak pemilik (Sunarto, 2009).

Pada motivasi signaling, manajemen menyajikan informasi keuangan (khususnya laba) yang diharapkan dapat memberi sinyal kemakmuran kepada pemegang saham. Laporan laba yang dapat memberi sinyal kemakmuran adalah laba yang relatif tumbuh dan stabil (sustainable). Sustainable earnings (laba yang berkelanjutan) adalah laba yang memiliki kualitas tinggi dan sebagai indikator laba di masa depan yang selanjutnya disebut persistensi laba (Sloan, 1996).

Stockholder akan diuntungkan jika manajemen laba digunakan untuk memberi sinyal tentang informasi privat yang dimiliki oleh manajer (Healy dan Palepu, 1995), atau untuk mengurangi biaya politik (political cost) (Watts dan Zimmerman, 1986). Namun, stockholder akan dirugikan jika manajemen laba digunakan untuk menghasilkan keuntungan abnormal pribadi bagi manajer, seperti menaikkan kompensasi (Healy,1985) atau mengurangi kemungkinan pemecatan ketika kinerja manajer rendah (Weisbach, 1988).

Manajemen laba didefinisikan sebagai kebijakan akuntansi atau tindakan-tindakan yang dipilih oleh manajer untuk mencapai beberapa tujuan khusus dalam pelaporan laba (Scott, 2009:403). Definisi ini mengandung pengertian bahwa manajemen laba dapat dilakukan dengan cara manipulasi akrual murni atau dengan memanipulasi aktivitas riil.

Manajemen laba dengan manipulasi akrual murni merupakan manipulasi laba dengan discretionary accrual yang tidak memiliki pengaruh terhadap aliran kas secara langsung. Penilaian pada akuntansi keuangan melibatkan "kebebasan manajerial (managerial discretion)". Idealnya, kebebasan ini meningkatkan nilai ekonomis atas angka 
akuntansi, karena kecakapan manajer dapat dikerahkan dalam membuat penilaian dan mengkomunikasikan informasi yang dimiliki melalui pilihan dan perkiraan akuntansi (Wild et al., 2005). Misalnya, seorang manajer dapat mengurangi penyisihan piutang tak tertagih berdasarkan informasi pihak dalam yaitu meningkatkan status keuangan seorang pelanggan utama. Namun, dalam praktiknya, banyak manajer yang menyalah gunakan kebebasan ini untuk melakukan manajemen laba dan mempercantik laporan keuangan, sehingga manajemen laba (earnings management) dapat mengurangi tingkat kepercayaan atas proses pelaporan.

Manipulasi aktivitas riil merupakan manipulasi yang dilakukan oleh manajemen melalui aktivitas perusahaan sehari-hari selama periode akuntansi berjalan dengan tujuan tertentu yaitu memenuhi target laba tertentu atau untuk menghindari kerugian. Beberapa teknik yang dapat dilakukan dalam manipulasi aktivitas riil antara lain manipulasi penjualan, produksi yang berlebihan (overproduction), dan pengurangan biaya diskresi (Roychowdhury, 2006).

a. Manipulasi penjualan dilakukan dengan cara meningkatkan penjualan secara temporer yaitu dengan menawarkan potongan harga yang tinggi atau dengan cara menawarkan jangka waktu kredit (piutang usaha) yang lebih ringan. Strategi ini menyebabkan aliran kas masuk kegiatan operasi periode sekarang lebih rendah dibandingkan tingkat penjualan normal dan pertumbuhan abnormal dari piutang.

b. Produksi yang berlebihan atas unit barang yang akan dijual dilakukan oleh manager pada perusahaan manufaktur. Produksi yang berlebihan menyebabkan turunnya rata-rata biaya per unit dan turunnya harga pokok penjualan. Turunnya harga pokok penjualan menyebabkan naiknya margin operasi dan menyebabkan aliran kas kegiatan operasi lebih rendah daripada tingkat penjualan normal. c. Mengurangi beban diskresi seperti beban penelitian dan pengembangan, beban iklan, beban administrasi dan umum, terutama pada periode saat pengeluaran tersebut tidak langsung menyebabkan pendapatan dan laba. Pengurangan beban diskresi pada akhir periode menyebab kan rekening biaya berkurang di bawah normal dan berdampak pada akrual abnormal yang positif. Dengan kata lain, strategi ini dapat meningkatkan laba dan arus kas periode saat ini, tetapi dengan risiko menurunkan arus kas periode mendatang.

\section{Perencanaan Pajak (Tax Planning)}

Manajemen akan merencanakan pembayaran pajak yang relatif sedikit, karena pembayaran pajak yang relatif besar dapat mengurangi optimalisasi alokasi sumber dana, dan tidak kurang membayar pajak, agar tidak membayar sanksi administrasi yang merupakan pemborosan dana (Suandy, 2006: 9).Perencanaan pajak (tax planning) merupakan upaya wajib pajak untuk meminimalkan pajak yang terutang melalui skema yang memang telah jelas diatur dalam peraturan perundang-undangan perpajakan dan sifatnya tidak menimbulkan perdebatan antara wajib pajak dan otoritas pajak.

Perencanaan pajak (tax planning) dapat dilakukan melalui penghindaran pajak (tax avoidance) dan penggelapan pajak (tax evasion) (Faiz, 2011). Penghindaran pajak (tax avoidance) diartikan sebagai suatu skema transaksi yang ditujukan untuk meminimalkan beban pajak dengan memanfaatkan kelemahan-kelemahan (loophole) ketentuan perpajakan suatu negara. Sebaliknya, penggelapan pajak (tax evasion) diartikan sebagai suatu skema memperkecil pajak terutang dengan cara tidak melaporkan sebagian penjualan atau memperbesar biaya dengan cara fiktif (Darussalam dan Septriadi, 2009).

Tax evasion biasa dilakukan perusahaan dengan cara membuat faktur palsu, tidak mencatat sebagian penjualan, atau laporan keuangan palsu, tetapi praktik penggelapan 
pajak tersebut sering terdeteksi, sehingga modus penggelapan pajak sekarang berubah. Perusahaan biasanya melaporkan pajak yang relatif kecil, sehingga akan ada pemeriksaan oleh aparat pajak. Di Indonesia, prestasi pegawai pajak ditentukan berdasarkan tagihan yang berhasil dikumpulkan, semua pegawai berlombalomba untuk dapat mengumpulkan setoran sebanyak-banyaknya. Hasil pemeriksaan biasanya kurang bayar yang sangat besar, sehingga perusahaan akan berusaha menyuap pegawai pajak, agar kurang bayar menjadi kecil, hal ini dianggap menguntungkan kedua belah pihak (Hutami, 2012).

Perencanaan pajak adalah salah satu insentif pajak yang mempengaruhi manajer perusahaan untuk melakukan manajemen laba (Wijaya dan Martani, 2011). Beberapa peneliti telah membuktikan bahwa perusahaan me-manage laba akuntansi untuk meminimalkan beban pajak dalam menanggapi penurunan tarif pajak penghasilan dengan mentransfer labanya pada periode setelah undang-undang perpajakan untuk memperoleh penghematan pajak (Roubi dan Richardson, 1998; Setyowati, 2002; Yamashita dan Otogawa, 2007; Wijaya dan Martani, 2011). Dengan demikian, terdapat hubungan positif antara manajemen laba dengan perencanaan pajak. Jika manajer perusahaan melakukan manajemen laba yang agresif guna meminimalkan beban pajak, berarti perusahaan dapat dikatakan melakukan perencanaan pajak yang agresif.

$\mathrm{H}_{1 \mathrm{a}}$ : Discretionary accruals berpengaruh positif terhadap perencanaan pajak.

$\mathrm{H}_{1 \mathrm{~b}}$ : Manipulasi penjualan berpengaruh positif terhadap perencanaan pajak.

$\mathrm{H}_{1 \mathrm{c}}$ : Peningkatan produksi secara berlebihan berpengaruh positif terhadap perencanaan pajak.

$\mathrm{H}_{1 \mathrm{~d}}$ : Pengurangan beban diskresi tunai berpengaruh positif terhadap perencanaan pajak.

\section{Persistensi Laba}

Laba dibedakan dalam dua kelompok: sustainable earnings (earnings persistent atau core earnings) dan unusual earnings atau transitory earnings. Persistensi laba merupakan laba yang mempunyai kemampuan sebagai indikator laba periode mendatang (future earnings) yang dihasilkan oleh perusahaan secara berulang-ulang (repetitive) dalam jangka panjang (sustainable). Sebaliknya, unusual earnings atau transitory earnings merupakan laba yang dihasilkan secara temporer dan tidak dapat dihasilkan secara berulang-ulang (non-repeating), sehingga tidak dapat digunakan sebagai indikator laba periode mendatang (Penman dan Zhang, 1999). Persistensi laba yang berkelanjutan (sustainable) dinyatakan sebagai laba yang mempunyai kualitas tinggi, sedangkan jika laba unusual, laba dinyatakan memiliki kualitas yang buruk.

Persistensi laba merupakan ukuran yang menjelaskan kemampuan perusahaan untuk mempertahankan jumlah laba yang diperoleh saat ini sampai satu periode masa depan (Sloan, 1996). Laba dikatakan persisten, apabila laba saat ini dapat digunakan sebagai pengukur laba periode mendatang (Sunarto, 2010). Konsep mengenai persistensi laba dipandang sebagai pengukur kualitas laba, karena persistensi laba mengandung unsur nilai predictive value, sehingga dapat digunakan pengguna laporan keuangan untuk mengevaluasi kejadiankejadian di masa lalu, sekarang, dan masa depan (Jonas dan Blanchet, 2000).

Kebijakan akrual diskresi yang dilakukan oleh manajemen menimbulkan dua konsekuensi. Pertama, jika kebijakan tersebut membawa keinformasian laba, maka kebijakan tersebut akan meningkatkan kualitas laba, sehingga laba semakin persisten. Kedua, jika kebijakan tersebut tidak membawa keinformasian laba, maka kebijakan tersebut akan menurunkan kualitas laba, sehingga laba menjadi kabur (opaque). Kekaburan laba (earnings opacity) berhubungan dengan keagresifan laba (earnings aggressiveness) dan perataan laba (earnings 
smoothing). Keagresifan laba merupakan laporan laba yang mengarah pada overstate earnings, sehingga laba yang dilaporkan menjadi kabur (opaque). Dengan kata lain, laba akuntansi tidak dapat mengukur kinerja ekonomi (Bhattacharya et al., 2003).

Manajemen laba secara oportunis terkait dengan earnings aggressiveness yang menyebabkan kekaburan informasi laba. Kebijakan akrual yang menghasilkan kekaburan laba akan mengurangi kualitas laba dan menyebabkan rendahnya persistensi laba (Sunarto, 2010). Jadi, semakin tinggi manajemen laba yang dilakukan oleh perusahaan, maka semakin rendah keinformatifan laba.Perusahaan dengan manajemen laba yang tinggi memiliki laba akuntansi yang kurang informatif dibandingkan dengan perusahaan dengan manajemen laba yang rendah (Ayers et al., 2008). Manajemen laba riil cenderung dilakukan sebelum tahun fiskal berakhir, sedangkan manajemen laba akrual cenderung dilakukan setelah tahun fiskal berakhir (Zang, 2006 dan Gunny, 2009). Saat manipulasi aktivitas riil tinggi, maka manajer akan cenderung mengurangi jumlah manajemen laba akrual, dan sebaliknya (Zang, 2006).

$\mathrm{H}_{2 \mathrm{a}}$ : Discretionary accruals berpengaruh negatif terhadap persistensi laba.

$\mathrm{H}_{2 b}$ : Manipulasi penjualan berpengaruh negatif terhadap persistensi laba.

$\mathrm{H}_{2 \mathrm{c}}$ : Peningkatan produksi secara berlebihan berpengaruh negatif terhadap persistensi laba.

$\mathrm{H}_{2 \mathrm{~d}}$ : Pengurangan beban diskresi tunai berpengaruh negatif terhadap persistensi laba.

Rendahnya persistensi laba perusahaan yang memiliki perbedaan laba akuntansi dan laba kena pajak kemungkinan disebabkan oleh banyaknya akrual dalam perusahaan (Hanlon, 2005). Perusahaan yang me miliki perencanaan pajak yang baik akan mendapat keuntungan dari tax shields, sehingga dapat meminimalisasi pembayaran pajak. Hal ini berarti, perencanaan pajak yang baik akan cenderung mengurangi laba bersih perusahaan guna mendapat keuntungan pajak melalui peluang kebijakan diskresi yang diberikan oleh PSAK dan peraturan perpajakan yang berlaku saat ini.

Peningkatan kesesuaian antara laba akuntansi dengan laba fiskal akan mengurangi perencanaan pajak perusahaan dan kandungan informasi laba akuntansi (Hanlon dan Shevlin, 2005; Hanlon et al., 2006; Hanlon et al., 2007). Semakin tinggi tingkat kesesuaian antara laba akuntansi dan laba fiskal, semakin rendah perencanaan pajak dan semakin rendah persistensi laba akuntansi (Atwood et al., 2010).

Perencanaan pajak yang agresif meningkatkan kekaburan informasi laba perusahaan (Balakhrisnan et al., 2011) atau mengurangi keinformatifan laba akuntansi (Chen et al., 2007). Kekaburan laba (earnings opacity) berhubungan dengan keagresifan laba (earnings aggressiveness) yang menyebabkan rendahnya persistensi laba (Sunarto, 2010). Perusahaan dengan perencanaan pajak yang tinggi relatif memiliki laba fiskal yang kurang informatif dibandingkan dengan perusahaan dengan perencanaan pajak yang rendah (Chen et al., 2007; Ayers et al., 2008). Semakin tinggi perencanaan pajak, semakin rendah keinformatifan laba akuntansi atau semakin rendah persistensi laba akuntansi.

$\mathrm{H}_{3}$ : Perencanaan pajak berpengaruh negatif terhadap persistensi laba.

\section{METODE PENELITIAN Jenis Penelitian}

Penelitian ini merupakan penelitian penjelasan (eksplanatory) yang berusaha untuk menjelaskan fenomena penggelapan pajak yang dilakukan perusahaan melalui perencanaan pajak dan manajemen laba. Adanya beberapa hipotesis yang dirumuskan dan ingin diuji dalam penelitian ini menunjukkan bahwa penelitian ini termasuk penelitian dengan tipe pengujian hipotesis (hypothesis testing) yang bersifat kausal, karena berusaha menjelaskan 
adanya hubungan sebab akibat antara manajemen laba, perencanaan pajak, dan persistensi laba.

\section{Populasi dan Sampel}

Populasi dalam penelitian ini adalah perusahaan yang terdaftar di Bursa Efek Indonesia. Data penelitian yang digunakan adalah data laporan keuangan perusahaan manufaktur yang terdaftar di Bursa Efek Indonesia periode 2006-2010 yang diperoleh dari situs resmi BEI di www.idx.co.id. Alasan penggunaan perusahaan manufaktur, karena salah satu pengukuran manajemen laba, yakni beban produksi tidak dapat diaplikasikan untuk perusahaan non manufaktur (Roychowdhury, 2006). Adapun kriteria penentuan sampel dalam penelitian ini adalah: (1) Perusahaan manufaktur yang terdaftar di BEI dan mempublikasi laporan keuangan auditan per 31 Desember, agar informasi yang dilaporkan lebih dapat dipercaya. (2) Perusahaan manufaktur yang mempublikasi laporan keuangan secara konsisten dan lengkap selama periode 20062010 dan menggunakan satuan mata uang rupiah dalam laporan keuangan. (3) Perusahaan manufaktur yang mencatat beban pajak tangguhan dalam laporan keuangannya. (4) Perusahaan tidak mengalami kerugian dalam laporan keuangan komersial dan laporan keuangan pajak, karena yang ingin diuji dalam penelitian ini adalah persistensi laba. Selain itu, kerugian dapat dikompensasi ke masa depan (carryforward) menjadi pengurang biaya pajak tangguhan dan diakui sebagai aset pajak tangguhan, sehingga dapat mengaburkan arti akun biaya pajak tangguhan (Hanlon, 2005). Berdasarkan kriteria tersebut, jumlah sampel yang digunakan dalam penelitian ini terlihat dalam tabel 1.

Tabel 1

Prosedur Pemilihan Sampel

Jumlah perusahaan manufaktur yang menjadi sampel penelitian untuk tahun 2006 dan 2010 diperoleh dengan rincian sebagai berikut:

\begin{tabular}{lc}
\hline Jumlah perusahaan yang terdaftar di BEI & 428 \\
Jumlah perusahaan non manufaktur & 226 \\
Jumlah perusahaan manufaktur & 202 \\
Laporan keuangan tidak berakhir pada 31 Desember, data tidak & 78 \\
lengkap, dan tidak menggunakan satuan mata uang rupiah & \\
Tidak mencatat beban pajak tangguhan & 3 \\
Melaporkan kerugian & 81 \\
Jumlah perusahaan yang menjadi sampel & 40 \\
Jumlah dalam perusahaan tahun & 200 perusahaan tahun \\
& (firms-years) \\
\hline
\end{tabular}

\section{Metode Pengumpulan Data}

Dalam penelitian ini, data yang digunakan adalah data sekunder berupa laporan keuangan tahunan perusahaan yang telah diaudit periode 2006-2010, yang di peroleh melalui www.idx.co.id dan harga pasar saham perusahaan yang diperoleh melalui www.duniainvestasi.com. Teknik pengumpulan data yang digunakan adalah pengumpulan data arsip (archival).

\section{Operasionalisasi Variabel}

Laba Akuntansi

Laba akuntansi, yakni selisih pendapatan dan keuntungan setelah dikurangi beban dan kerugian (Wild et al., 2005: 407). Dalam penelitian ini, yang ingin diuji adalah persistensi laba, yakni laba yang mempunyai kemampuan sebagai indikator laba periode mendatang (future earnings) yang dihasilkan oleh perusahaan secara 
berulang-ulang (repetitive) dalam jangka panjang (sustainable) (Sunarto, 2010). Construct ini diukur dengan koefisien regresi $\left(\mathrm{a}_{1}\right)$ antara laba akuntansi sebelum pajak satu periode ke depan dengan laba akuntansi sebelum pajak periode sekarang. Persamaannya adalah sebagai berikut (Hanlon, 2005):

$\mathrm{PTBI}_{\mathrm{t}+1}=\mathrm{a}_{0}+\mathrm{a}_{1} \mathrm{PTBI}_{\mathrm{t}}$

Keterangan:

PTBI $_{\mathrm{t}+1}$ : Pre-tax book income pada periode $\mathrm{t}+1$.

$\mathrm{PTBI}_{\mathrm{t}}$ : Pre-tax book income pada periode $\mathrm{t}$. : error term.

\section{Manajemen Laba}

Manajemen laba adalah kebijakan akuntansi atau tindakan-tindakan yang dipilih oleh manajer untuk mencapai beberapa tujuan khusus dalam pelaporan laba (Scott, 2009: 403). Manajemen laba dilakukan oleh para manajer, karena manajer memiliki kewenangan untuk memilih metode dan menetapkan kebijakan akuntansi. Construct ini terdiri atas:

a. Manajemen laba akrual adalah bentuk manajemen laba yang dilakukan dengan memanfaatkan kebebasan dalam memilih kebijakan akuntansi. Construct ini diproksikan dengan akrual diskresioner (discretionary accruals) menggunakan model pengukuran performance matched discretionary accruals yang diajukan oleh Khotari et al. (2005).

Model perhitungan discretionary accruals menggunakan model performance matched discretionary accruals adalah:

$\mathrm{TACC}_{\mathrm{jt}}=\mathrm{NIBE}_{\mathrm{jt}}-\mathrm{CFO}_{\mathrm{jt}}$

$\mathrm{TACC}_{\mathrm{jt}} / \mathrm{TA}_{\mathrm{jt}-1}=\beta_{1}\left(1 / \mathrm{TA}_{\mathrm{jt}-1}\right)+\beta_{2}\left(\Delta \mathrm{REV}_{\mathrm{jt}} /\right.$

$\left.\mathrm{TA}_{\mathrm{jt}-1}\right)+\beta_{3}\left(\mathrm{PPE}_{\mathrm{jt}} / \mathrm{TA}_{\mathrm{jt}-1}\right)+\beta_{4}\left(\mathrm{ROA}_{\mathrm{jt}} / \mathrm{TA}_{\mathrm{jt}-}\right.$

$$
\text { 1) }+ \text { jt. }
$$

Berdasarkan persamaan di atas, NDACC (non-discretionary accruals) dapat dihitung dengan memasukkan kembali koefisienkoefisien $\beta$.
$\mathrm{DACC}_{\mathrm{jt}}=\beta_{1}\left(1 / \mathrm{TA}_{\mathrm{jt}-1}\right)+\beta_{2}\left(\Delta \mathrm{RE} \mathrm{V}_{\mathrm{jt}}-\Delta \mathrm{REC}_{\mathrm{jt}}\right)$

$\left./ \mathrm{TA}_{\mathrm{jt}-1}\right)+\beta_{3}\left(\mathrm{PPE}_{\mathrm{jt}} / \mathrm{TA}_{\mathrm{jt}-1}\right)+\beta_{4}\left(\mathrm{ROA}_{\mathrm{jt}} / \mathrm{TA}_{\mathrm{jt} 1}\right)$

$\mathrm{DACC}_{\mathrm{jt}}=\left(\mathrm{TACC}_{\mathrm{jt}} / \mathrm{TA}_{\mathrm{jt}-1}\right)-\mathrm{NDACC}_{\mathrm{jt} .}$.

Keterangan:

TACC $_{\mathrm{jt}}$ : Total akrual perusahaan $\mathrm{j}$ pada periode $t$.

$\mathrm{NIBE}_{\mathrm{jt}} \quad$ : Net income before extraordinary item perusahaan $\mathrm{j}$ pada periode $\mathrm{t}$.

$\mathrm{CFO}_{\mathrm{jt}} \quad$ : Operating cash flow perusahaan $\mathrm{j}$ pada periode $t$.

$\mathrm{TA}_{\mathrm{jt}-1} \quad$ : Total aset perusahaan $\mathrm{j}$ pada periode $t$.

$\triangle \mathrm{REV}_{\mathrm{jt}} \quad$ : Perubahan pendapatan perusahaan $\mathrm{j}$ pada periode $t$.

$\mathrm{PPE}_{\mathrm{jt}} \quad$ : Nilai aset tetap bersih perusahaan $\mathrm{j}$ pada periode $\mathrm{t}$.

$\mathrm{ROA}_{\mathrm{jt}} \quad$ : Return on Assets perusahaan $\mathrm{j}$ pada periode $t$.

$\mathrm{NDACC}_{\mathrm{jt}}$ : Non-discretionary accruals perusahaan $\mathrm{j}$ pada periode $t$.

$\triangle \mathrm{REC}_{\mathrm{jt}}$ : Perubahan piutang usaha perusahaan $\mathrm{j}$ pada periode $\mathrm{t}$.

DACC $_{\mathrm{jt}}$ : Discretionary accruals perusahaan $\mathrm{j}$ pada periode $\mathrm{t}$.

b. Manajemen laba riil adalah bentuk manajemen laba yang dilakukan melalui manipulasi aktivitas operasional perusahaan (Roychowdhury, 2006). Construct ini diproksikan dengan abnormal cash flow from operations (abn.CFO), abnormal production costs (abn.PROD), dan abnormal discretionary expenses (abn.DISCR).

1. Abnormal Cash Flow from Operations

Perhitungan normal CFO:

CFOjt $/$ Ajt-1=a0+a1(1/ Ajt-1)+ $\beta 1(\mathrm{St} /$

$A j t-1)+\beta 2(\Delta S \mathrm{jt} / \mathrm{Ajt} 1)+\mathrm{jt}$.

Selanjutnya, koefisien regresi persamaan 6 di atas digunakan untuk menghitung nilai normal CFO. Abnormal CFO adalah arus kas operasi aktual dikurangi dengan normal CFO. 
2. Abnormal Production Costs

Normal COGS:

COGSjt $/$ Ajt-1=a0+a1(1/Ajt-1)+ $\beta 1$

$($ Sjt/Ajt-1)+ jt.

Normal $\triangle \mathrm{INV}$ :

$\Delta \mathrm{INVjt} / \mathrm{Ajt}-1=\mathrm{a} 0+\mathrm{a} 1(1 / \mathrm{Ajt}-1)+\beta 1(\Delta \mathrm{Sjt}$

$/ A j t-1)+\beta 2(\Delta \mathrm{Sjt}-1 / \mathrm{Ajt} 1)+\mathrm{jt}$

Rowchowdhury (2006) merumuskan PRODjt $=$ COGSjt $-\Delta \mathrm{INVjt}$. Dengan menggunakan persamaan (7) dan (8), maka model estimasi untuk normal production costs adalah sebagai berikut: PRODjt/Ajt-1=a0+a1(1/Ajt-1)+ $\beta 1($ Sjt $/$ Ajt-1 $)+\beta 2(\Delta \mathrm{Sjt} / \mathrm{Ajt}-1)+\beta 3(\Delta \mathrm{Sjt}-1 /$ Ajt$1)+\mathrm{jt}$

Koefisien regresi persamaan 9 di atas digunakan untuk menghitung nilai normal normal production costs. Abnormal PROD adalah PROD aktual dikurangi dengan normal PROD.

3. Abnormal Discretionary Expenses Normal discretionary expenses:

DISEXPjt $/$ Ajt-1 $=a 0+a 1(1 /$ Ajt-1) $+\beta 1$

$($ Sjt-1/At-1)+ jt.

Koefisien regresi persamaan 10 di atas digunakan untuk menghitung nilai normal discretionary expenses. Abnormal DISEXP adalah DISEXP aktual dikurangi dengan normal DISEXP.

Keterangan:

CFOjt : Arus kas operasi perusahaan $\mathrm{j}$ pada periode $\mathrm{t}$.

COGSjt : Harga pokok penjualan perusahaan $\mathrm{j}$ pada periode t.

$\Delta \mathrm{INVjt} \quad$ : Perubahan persediaan perusahaan $j$ pada periode $t$.

PRODjt : Beban produksi perusahaan $j$ pada periode $t$.

DISEXPjt : Pengeluaran diskresi perusahaan $j$ pada periode $t$.

Sjt : Penjualan perusahaan j pada periode $t$.
$\Delta S j t \quad$ : Perubahan penjualan perusahaan $\mathrm{j}$ pada periode $t$.

$\Delta S j t-1$ : Perubahan penjualan perusahaan $\mathrm{j}$ pada periode $\mathrm{t}-1$.

Ajt-1 : Total aset perusahaan $\mathrm{j}$ pada periode $\mathrm{t}-1$.

\section{Perencanaan Pajak}

Perencanaan pajak (tax planning) merupakan langkah yang ditempuh oleh wajib pajak untuk meminimumkan beban pajak tahun berjalan maupun tahun yang akan datang, agar pajak yang dibayar dapat ditekan seefisien mungkin dan dengan berbagai cara yang memenuhi ketentuan perpajakan (Wijaya dan Martani, 2011). Construct ini diproksikan dengan current effective tax rate (CurETR) (Chen et al., 2007; Ayers et al., 2008). Current effective tax rate (CUrETR) untuk tiap periode adalah current tax expense dibagi dengan pre-taxable income. Namun, untuk mengurangi pengaruh item pajak transitori, maka digunakan rumus sebagai berikut:

$\operatorname{CurETRj}_{t}=\frac{\left(\sum_{\mathrm{m}=\mathrm{t}-4}^{\mathrm{t}} \mathrm{CTE}_{\mathrm{jm}}-\sum_{\mathrm{m}=\mathrm{t}-4}^{\mathrm{t}} \mathrm{DTE}_{\mathrm{jm}}\right)}{\sum_{\mathrm{m}=\mathrm{t}-4}^{\mathrm{t}} \mathrm{PTBI}_{\mathrm{jm}}}$

Keterangan:

CUrETR $_{\mathrm{j} t}$ : Current efective tax rate perusahaan $\mathrm{j}$ pada periode $\mathrm{t}$.

$\sum_{\mathrm{m}=\mathrm{t}-4}^{\mathrm{t}} \mathrm{CTE}_{\mathrm{jm}}$ : Jumlah current tax expense perusahaan j selama 5 tahun dari periode $\mathrm{t}-4$ sampai periode $\mathrm{t}$.

$\sum_{\mathrm{m}=\mathrm{t}-4}^{\mathrm{t}} \mathrm{DTE}_{\mathrm{jm}}$ : Jumlah deferred tax expense perusahaan $\mathrm{j}$ selama 5 tahun dari periode $\mathrm{t}-4$ sampai periode $\mathrm{t}$.

$\sum_{\mathrm{m}=\mathrm{t}-4}^{\mathrm{t}} \mathrm{PTBI}_{\mathrm{jm}}$ : Jumlah pre-tax book income perusahaan j selama 5 tahun dari periode $\mathrm{t}-4$ sampai periode $\mathrm{t}$.

Current tax expense (CTE) dihitung menggunakan actual cash taxes paid (pajak aktual yang dibayar dengan kas). Perhitungan ini dilakukan, karena perhitungan beban pajak kini menggunakan akuntansi berbasis akrual yang kemungkinan memiliki kesalahan dalam mengukur beban pajak 
aktual yang harus dibayar oleh perusahaan kepada pemerintah (Ayers et al., 2008).

\section{Ukuran perusahaan (size)}

Ukuran perusahaan diukur dari natural logaritma nilai pasar ekuitas perusahaan pada akhir tahun, yaitu jumlah saham beredar pada akhir tahun dikalikan dengan harga pasar saham akhir tahun (Siregar dan Utama, 2006).

\section{Metode Analisis}

Penelitian ini menggunakan metode regresi time-series cross-section (pooled regression). Sebelum dilakukan pengujian regresi, terlebih dahulu dilakukan uji stasionaritas data dan uji asumsi klasik untuk mengetahui apakah data yang digunakan telah memenuhi syarat ketentuan dalam model regresi. Pengolahan data dilakukan dengan menggunakan software Eviews Ver 6.0.

Model estimasi regresi linier berganda yang digunakan dalam penelitian ini adalah:

$\mathrm{PTBI}_{\mathrm{t}+1}=\mathrm{a}_{0}+\mathrm{a}_{1} \mathrm{Abn} \cdot \mathrm{CFO}_{\mathrm{t}}+\mathrm{a}_{2} \mathrm{Abn} \cdot \mathrm{PROD}_{\mathrm{t}}+\mathrm{a}_{3}$ Abn.DISEXP $\mathrm{P}_{\mathrm{t}}+\mathrm{a}_{4} \mathrm{DACC}_{\mathrm{t}}+\mathrm{a}_{5}$ TaxPlan ${ }_{\mathrm{t}}+\mathrm{a}_{6} \mathrm{SIZE}_{\mathrm{t}}+{ }_{\mathrm{t}+1 . .}$
$\operatorname{TaxPlan}_{\mathrm{t}}=\mathrm{a}_{0}+\mathrm{a}_{1} \mathrm{Abn} . \mathrm{CFO}_{\mathrm{t}}+\mathrm{a}_{2}$

$$
\text { Abn.PROD }{ }_{\mathrm{t}}+\mathrm{a}_{3} \mathrm{Abn} \text {.DISEXP } \mathrm{t}_{\mathrm{t}}+\mathrm{a}_{4} \mathrm{DA}
$$

$\mathrm{CC}_{\mathrm{t}}+\mathrm{a}_{5} \mathrm{SIZE}_{\mathrm{t}}+{ }_{\mathrm{t}+1}$

Keterangan:

$\mathrm{PTBI}_{\mathrm{t}+1} \quad=$ Persistensi laba satu periode ke depan.

$\mathrm{a}_{0} \quad=$ koefisien konstanta.

$\mathrm{a}_{1}-\mathrm{a}_{6} \quad=$ koefisien variabel bebas.

Abn. $\mathrm{CFO}_{\mathrm{t}}=$ Abnormal Cash Flow from Operation.

Abn.PROD ${ }_{\mathrm{t}}=$ Abnormal Production Cost .

Abn.DISEXP $\mathrm{t}_{\mathrm{t}}=$ Abnormal Discretionary Expenses.

DACC $_{\mathrm{t}}=$ Discretionary Accruals.

TaxPlan $_{\mathrm{t}} \quad=$ Tax Planning.

$\mathrm{SIZE}_{\mathrm{t}} \quad=$ Ukuran perusahaan.

$\mathrm{t}+1 \quad=$ residual regresi.

Analisis regresi ini bertujuan untuk membuktikan bahwa manajemen laba berpengaruh terhadap perencanaan pajak yang selanjutnya mempengaruhi persistensi laba. Analisis dilakukan dengan melihat nilai koefisien determinasi yang disesuaikan (adjusted R-squared) dari regresi tersebut.

Tabel 2

Statistik deskriptif data penelitian (disajikan dalam milyaran Rp kecuali ROA)

\begin{tabular}{lrrrr}
\hline \hline & Rata-rata & Maksimum & Minimum & Deviasi Standar \\
\hline Arus kas operasi & 1.570 & 29.800 & -447 & 4.530 \\
Harga pokok penjualan & 5.810 & 103.000 & 21,100 & 12.900 \\
Pengeluaran diskresi & 1.550 & 24.600 & 4,850 & 3.840 \\
Biaya produksi & 5.650 & 9.600 & 22,400 & 12.600 \\
Total akrual & 1.090 & 11.800 & $-7,020$ & 1.320 \\
Persediaan & 1.270 & 20.200 & 9,140 & 3.000 \\
Laba bersih sebelum pajak & 1.700 & 25.600 & 1,360 & 4.280 \\
Penjualan (pendapatan bersih) & 9.360 & 130.000 & 61,300 & 18.700 \\
Piutang & 754 & 9.390 & 3,520 & 1.330 \\
Laba operasi & 1.680 & 26.500 & -67 & 4.140 \\
Aset tetap bersih & 3.640 & 76.400 & 1,360 & 10.900 \\
Total asset & 7.660 & 97.900 & 42,100 & 17.400 \\
ROA & 16,291 & 57,070 & 0,020 & 13,100 \\
Beban pajak (cash) & 932 & 21.900 & 0,774 & 3.100 \\
Beban pajak tangguhan & $-0,903$ & 877 & -380 & 98.900 \\
\hline
\end{tabular}




\section{ANALISIS DAN PEMBAHASAN \\ Hasil Uji Statistik Deskriptif \\ Hasil Uji Hipotesis}

Tabel 3

Hasil Uji Hipotesis 1

\begin{tabular}{|c|c|c|}
\hline \multicolumn{3}{|c|}{ TaxPlan $_{t}=a_{0}+a_{1}$ Abn.CFO ${ }_{t}+a_{2}$ Abn.PROD ${ }_{t}+a_{3}$ Abn.DISEXP ${ }_{t}+a_{4}$ DACC $_{t}+a_{5}$ SIZE $_{t}+{ }_{t+1}$} \\
\hline Variabel & Koefisien & Prob \\
\hline Abnormal cashflow from operation & 0,228 & 0,229 \\
\hline Abnormal production cost & 0,058 & 0,627 \\
\hline Abnormal discretionary expenditure & 0,085 & 0,566 \\
\hline Discretionary accruals & 0,178 & 0,411 \\
\hline Firm size & $-0,013$ & 0,341 \\
\hline
\end{tabular}

Tabel 3 menunjukkan tidak satupun proksi manajemen laba yang memiliki pengaruh signifikan terhadap perencanaan pajak. Tindakan perusahaan melakukan manipulasi penjualan, produksi berlebihan, menunda beban diskresi tunai, dan mengambil kebijakan akrual diskresi tidak mempengaruhi perencanaan pajak perusahaan. Ukuran perusahaan juga tidak mempengaruhi perencanaan pajak secara signifikan. Dengan demikian, hasil penelitian ini menolak $\mathrm{H}_{1 \mathrm{a}}, \mathrm{H}_{1 \mathrm{~b}}, \mathrm{H}_{1 \mathrm{c}}$ dan $\mathrm{H}_{1 \mathrm{~d}}$ yang menyatakan bahwa manajemen laba riil dan manajemen laba akrual berpengaruh positif terhadap perencanaan pajak, sehingga dapat disimpulkan bahwa manajemen laba tidak mempengaruhi perencanaan pajak. Dengan kata lain, perusahaan tidak melakukan manajemen laba dalam melakukan perencanaan pajak. Hal ini mengandung arti bahwa manajemen laba yang dilakukan perusahaan tidak sekaligus bertujuan untuk memanipulasi jumlah pajak yang akan dibayar oleh perusahaan.

Penelitian ini tidak menemukan bukti bahwa manajemen laba dilakukan untuk mendukung perencanaan pajak, maka dapat dikatakan bahwa keinformatifan laba fiskal tidak berkurang, karena adanya manajemen laba. Perilaku ini kemungkinan disebabkan oleh perbedaan kebijakan pelaporan keuangan perusahaan dengan kebijakan dalam melakukan strategi pajak, karena manajer perusahaan mengatur laba untuk mencapai target kinerja yang kemungkinan bertentangan dengan tujuan pajak (Ayers et al., 2006). Oleh karena ukuran perusahaan tidak berpengaruh terhadap perencanaan pajak, maka besar kecilnya perusahaan tidak mempengaruhi perilaku perencanaan pajak perusahaan.

Perilaku manajemen perusahaan yang melakukan manajemen laba untuk memberi informasi privat kepada pemegang saham bertentangan dengan tujuan perilaku perencanaan pajak perusahaan yang bersifat jangka pendek dan cenderung tidak sustainable. Jadi, saat perencanaan pajak tidak dipengaruhi oleh manajemen laba, hal ini kemungkinan disebabkan oleh perbedaan tujuan perusahaan dalam melakukan manajemen laba dan perencanaan pajak, karena manajemen laba bertujuan untuk menyajikan laba akuntansi yang berkelanjutan, sedangkan laba fiskal tidak berkelanjutan. Ukuran perusahaan tidak berpengaruh terhadap perencanaan pajak. Dengan demikian, besar kecilnya perusahaan tidak mempengaruhi perilaku perencanaan pajak perusahaan. 
Tabel 4

Hasil Uji Hipotesis 2 dan 3

\begin{tabular}{|c|c|c|}
\hline \multicolumn{3}{|c|}{$\begin{array}{c}\text { PTBI }_{t+1}=\alpha_{0}+\alpha_{1} \text { Abn.CFO } \\
a_{6} \text { SIZE }_{t}+\alpha_{t+1} \text { Abn.PROD }\end{array}$} \\
\hline Variabel & Koefisien & Prob \\
\hline Abnormal cashflow from operation & 0,952 & $0,020^{* *}$ \\
\hline Abnormal production cost & 0,030 & 0,918 \\
\hline Abnormal discretionary expenditure & 0,612 & $0,026^{* *}$ \\
\hline Discretionary accruals & 1,426 & $0,005^{* * *}$ \\
\hline Cash effective tax rate & $-0,010$ & 0,928 \\
\hline Firm size & 0,060 & $0,001^{* * *}$ \\
\hline
\end{tabular}

Hasil estimasi tabel 4 menunjukkan abnormal cash flow from operation (Abn.CFO), abnormal discretionary expenditure (Abn. DISEXP), discretionary accruals (DACC), dan ukuran perusahaan (SIZE) mempengaruhi persistensi laba secara signifikan. Hasil penelitian ini menolak $\mathrm{H}_{2 \mathrm{a}}, \mathrm{H}_{2 b}, \mathrm{H}_{2 c}, \mathrm{H}_{2 \mathrm{~d}}$, sehingga membuktikan bahwa perusahaan di Indonesia melakukan manajemen laba untuk tujuan efisiensi atau tidak oportunis yakni agar laba dapat dijadikan pengukur kinerja perusahaan yang lebih baik di masa datang (laba yang persisten). Dengan demikian, hasil penelitian ini mendukung teori keagenan (motivasi signaling). Dalam hal ini, manajer dimotivasi untuk menyajikan angka laba yang mampu mencerminkan kinerja perusahaan di masa depan, sehingga pihak-pihak yang berkepentingan dengan perusahaan mampu mengambil keputusan yang lebih baik dalam menilai perusahaan.

Pengaruh positif manajemen laba terhadap persistensi laba terkait dengan sinyal kompetensi manajemen perusahaan (Bartov et al., 2002). Perusahaan menggunakan discretionary accruals sebagai sinyal nilai perusahaan (Subramanyam, 1996). Graham et al. (2005) menemukan bahwa 74,1\% eksekutif perusahaan berusaha mencapai tolak ukur laba, karena hal tersebut mampu membantu menyampaikan prospek pertumbuhan perusahaan di masa depan kepada para pemegang saham. Manajemen perusahaan tidak mungkin hanya meng- andalkan manajemen laba akrual untuk mengatur laba (Roychowdhury, 2006).

Perusahaan yang melakukan manajemen laba riil untuk mencapai target laba memiliki kinerja masa depan yang lebih baik dibandingkan dengan perusahaan yang tidak melakukan manajemen laba riil, karena manajer perusahaan menggunakan kebijakan diskresi operasi untuk memperoleh manfaat yang memungkinkan kinerja perusahaan yang lebih baik di masa depan. Manajer mengatur laba untuk mengkomunikasi informasi privat tentang prospek perusahaan dan menilai biaya serta manfaat manajemen laba riil secara hati-hati untuk menghindari penurunan kinerja perusahaan di masa depan (Taylor dan $\mathrm{Xu}$, 2008).

Penelitian ini menggunakan tiga proksi manajemen laba riil yang mewakili tindakan perusahaan dalam mengatur kegiatan operasi guna menghindari melaporkan rugi. Namun, hasil penelitian ini membuktikan bahwa manipulasi penjualan yang dilakukan dengan memberi potongan harga dan persyaratan kredit yang lebih lunak, serta menunda pengeluaran diskresi tunai dapat meningkatkan nilai perusahaan yang memungkinkan manajer menyajikan laba yang lebih mencerminkan kinerja perusahaan di masa depan. Sedangkan, tindakan untuk mengatur angka laba dengan meningkatkan jumlah produksi barang secara berlebihan terbukti tidak mempengaruhi persistensi 
laba.Ukuran perusahaan juga terbukti memiliki pengaruh positif terhadap persistensi laba. Dengan demikian, semakin besar perusahaan, semakin persisten laba perusahaan.

Manipulasi penjualan mengarah pada perilaku manajer yang berusaha meningkatkan penjualan selama periode berjalan untuk mencapai target laba. Pencapaian target laba berhubungan positif dengan kinerja perusahaan di masa depan (Gunny, 2005). Jadi, manipulasi penjualan yang dilakukan perusahaan dapat membantu manajemen perusahaan untuk mencapai target laba yang mengarah pada persistensi laba. Demikian juga dengan penundaan pengeluaran diskresi tunai seperti penundaan investasi Research $\mathcal{E}$ Development yang manfaatnya belum pasti akan menambah nilai perusahaan di masa depan.

Manipulasi harga pokok penjualan dengan meningkatkan produksi secara berlebihan untuk memanfaatkan biaya overhead tetap tidak mempengaruhi persistensi laba, karena tindakan manajemen laba riil ini merupakan cerminan dari niat perusahaan untuk melakukan pemotongan harga, pemberian persyaratan kredit yang lunak untuk meningkatkan penjualan dan/atau penurunan harga pokok penjualan (Taylor dan $\mathrm{Xu}, 2008)$. Dengan demikian, produksi berlebih dan manipulasi penjualan merupakan tindakan yang tidak terpisah satu sama lain. Dalam hal ini perusahaan harus memiliki persediaan yang cukup banyak untuk memanipulasi penjualan dan pemanfaatan biaya overhead tetap tidak boleh melebihi biaya marjinal periode berjalan. Jika biaya marjinal meningkat, maka peningkatan penjualan juga akan meningkatkan harga pokok penjualan.

Pengaruh positif manajemen laba riil terhadap persistensi laba merupakan tindakan manajemen yang berusaha mencapai tolak ukur laba untuk memberi manfaat bagi perusahaan dan memungkinkan kinerja yang lebih baik di masa depan. Manfaat yang diperoleh perusahaan dalam usaha mencapai tolak ukur laba meliputi pening- katan harga saham, meningkatkan kredibilitas manajemen guna memenuhi harapan para pemegang saham, dan menghindari tuntutan hukum (Gunny, 2009). Graham et al. (2005) menemukan bahwa 86,3\% eksekutif perusahaan yakin pencapaian target laba membantu meningkatkan kredibilitas perusahaan di pasar modal. Manajemen perusahaan melakukan manajemen laba riil selama manfaat yang diterima lebih besar dari biaya yang akan dikeluarkan oleh perusahaan (Gunny, 2009).

Hasil penelitian ini juga menunjukkan perencanaan pajak dan abnormal production cost (Abn.PROD) tidak berpengaruh terhadap persistensi laba, sehingga menolak $\mathrm{H}_{3}$. Hal ini membuktikan bahwa perencanaan pajak tidak berpengaruh terhadap persistensi laba. Perilaku ini kemungkinan disebabkan oleh tujuan utama perencanaan pajak yang efektif adalah untuk memaksimalkan return setelah pajak, bukan untuk meminimalisasi beban pajak (McGuire et al., 2012). Oleh karena manfaat pajak dan biaya pelaporan keuangan saling bertentangan satu sama lain.

Beberapa peneliti di Indonesia (Wulandari et al., 2004; Wijaya dan Martani, 2011; serta Subagyo dan Oktavia, 2010) telah menemukan bukti bahwa perusahaan memani pulasi laba untuk meminimalkan pembayaran pajak. Dengan demikian, perencanaan pajak di Indonesia cenderung agresif, karena hanya memiliki fokus jangka pendek dan tidak berkelanjutan. Akibatnya, perencanaan pajak kurang mencerminkan informasi mengenai persistensi laba perusahaan. Klijnveld et al. (2007) berpendapat bahwa perencanaan pajak yang berkelanjutan merupakan tujuan jangka panjang penting bagi perusahaan, karena perubahan yang tak terduga dalam nilai pajak perusahaan dipandang sebagai sinyal dari manajemen yang buruk oleh para analis keuangan.

Semakin berkelanjutan strategi pajak perusahaan, semakin persisten laba, arus kas, dan akrual sebelum pajak perusahaan (McGuire et al., 2012). Strategi pajak yang berkelanjutan memberi sinyal mengenai 
seberapa besar harapan manajer perusahaan tentang sejauh mana laba saat ini mampu bertahan ke masa depan. Strategi pajak yang berkelajutan juga digunakan oleh investor untuk menilai persistensi laba dan komponen-komponen laba perusahaan.

Minimalisasi pajak dan keberlanjutan (sustainability) mewakili dua dimensi yang berbeda dari strategi pajak perusahaan (McGuire et al., 2012). Strategi pajak yang berkelanjutan memiliki fokus jangka panjang dengan mempertahankan kekonsistenan hasil dari penghindaran pajak dari waktu ke waktu, sedangkan minimalisasi pajak memiliki fokus jangka pendek dengan meminimalisasi kewajiban pajak selama satu periode. Strategi pajak perusahaan di lakukan melalui berbagai aktivitas perencanaan pajak.

Salah satu perusahaan tambang dunia yang memiliki anak perusahaan di Indonesia, yakni Rio Tinto Group memiliki pernyataan misi untuk menyelaraskan strategi pajak dengan strategi bisnis perusahaan dan menuntut departemen pajak perusahaan, agar memiliki strategi pajak yang transparan dan berlanjut dalam jangka panjang (Tinto, 2011). Misi perusahaan seperti ini masih jarang ditemui pada perusahaanperusahaan di Indonesia, sehingga kemungkinan fenomena penggelapan pajak merupakan akibat dari perencanaan pajak yang bersifat jangka pendek, yakni minimalisasi beban pajak selama satu periode pelaporan.

\section{SIMPULAN, SARAN, DAN KETERBATASAN \\ Simpulan}

Penelitian ini bertujuan untuk menemukan bukti empiris dampak manajemen laba terhadap perencanaan pajak yang selanjutnya mempengaruhi persistensi laba. Penelitian ini dilakukan, karena beberapa bukti empiris sebelumnya telah membuktikan bahwa manajemen laba dan perencanaan pajak terkait satu sama lain dan samasama memiliki potensi dalam mempengaruhi laba akuntansi dan laba fiskal.
Hasil penelitian ini menunjukkan bahwa manajemen laba cenderung dilakukan untuk tujuan efisiensi. Perusahaan melakukan manajemen laba untuk menyampaikan informasi privat tentang prospek perusahaan di masa depan kepada stakeholders serta sinyal kredibilitas manajemen perusahaan. Perilaku ini mendukung teori keagenan. Dalam hal ini, manajemen didorong oleh motivasi signaling.

Perilaku manajemen laba perusahaan ini dilakukan melalui manipulasi penjualan, menunda pengeluaran diskresi tunai, dan kebijakan akrual diskresi. Sedangkan, peningkatan produksi secara berlebihan tidak berpengaruh terhadap persistensi laba perusahaan. Persistensi laba juga tidak dipengaruhi oleh perencanaan pajak. Baik manajemen laba riil maupun akrual tidak mempengaruhi perencanaan pajak perusahaan. Hal ini menunjukkan adanya perbedaan tujuan pelaporan keuangan dan pelaporan pajak, karena manajemen laba dilakukan untuk memberi sinyal kemakmuran kepada stakeholders, sedangkan perencanaan pajak cenderung bertujuan untuk meminimalisasi beban pajak dalam jangka pendek.

Manajemen laba memiliki pengaruh terhadap persistensi laba, sehingga semakin besar manajemen laba yang dilakukan perusahaan, semakin persisten laba yang di miliki oleh perusahaan.Variabel kontrol ukuran perusahaan juga memiliki pengaruh terhadap persistensi laba, tetapi tidak mempengaruhi besarnya perencanaan pajak. Semakin besar ukuran perusahaan, semakin persisten laba perusahaan. Besar kecilnya ukuran perusahaan tidak mempengaruhi perencanaan pajak.

\section{Keterbatasan}

Penelitian ini memiliki beberapa keterbatasan antara lain: (1) Penelitian ini menggunakan tiga teknik manajemen laba riil yakni manipulasi penjualan, produksi berlebih, dan pengurangan beban diskresi tunai. Peneliti sebelumnya ada yang membedakan teknik manajemen laba dengan 
lebih rinci yakni penurunan beban diskresi $\mathrm{R} \& \mathrm{D}$ (research and development), penurunan beban diskresi SG\&A (sales, general, and advertising), pengaturan waktu penjualan aset tetap (Taylor dan $\mathrm{Xu}, 2008)$. (2) Penelitian ini secara tidak langsung membuktikan bahwa manajemen berusaha mencapai target laba untuk memberi informasi yang lebih tepat tentang prospek kinerja perusahaan di masa depan, tetapi peneliti belum menggunakan tolak ukur laba dalam menjelaskan pengaruh manajemen laba terhadap persistensi laba. (3) Data beban pajak tangguhan dalam laporan keuangan perusahaan lebih banyak dicantumkan dalam catatan atas laporan keuangan, sedangkan laporan keuangan yang diperoleh peneliti sebagian besar hanya meliputi neraca, laporan laba rugi, laba ditahan, dan arus kas. Jika hal ini tetap dipaksakan, maka sampel penelitian akan semakin kecil, sehingga peneliti akan memiliki hambatan normalitas data. (4) Persistensi laba dalam penelitian ini merupakan persistensi laba total, sehingga peneliti tidak dapat menarik kesimpulan mengenai komponen laba yang menjadi penyebab rendahnya persistensi laba akibat perencanaan pajak perusahaan.

\section{Saran}

Saran untuk penelitian selanjutnya: (1) Peneliti berikutnya dapat meneliti pengaruh penurunan beban diskresi R\&D (research and development), penurunan beban diskresi SG\&A (sales, general, and advertising), dan pengaturan waktu penjualan aset tetap terhadap persistensi laba. (2) Peneliti berikutnya dapat menggunakan reference point laba nol dan laba periode sebelumnya sebagai tolak ukur laba seperti yang dilakukan oleh Gunny (2009). Penggunaan reference point juga dapat membantu peneliti berikutnya untuk menguji pengaruh manajemen laba berdasarkan teori prospek. (3) Pengukuran manajemen laba akrual pada penelitian berikutnya dapat menggunakan proksi short-term dan long-term discretionary accruals dengan model performance matched discretionary accruals, karena akrual terbagi menjadi akrual jangka pendek terkait dengan pos modal kerja dan akrual jangka panjang seperti penyusutan dan amortisasi. Pengukuran proksi perencanaan pajak dapat menggunakan ETR (Efective Tax Rate) dan CurETR (Current Efective Tax Rate). Kedua proksi tersebut berdasarkan beban pajak kini akrual. (4) Pengukuran persistensi laba untuk penelitian berikutnya dapat menggunakan persistensi akrual dan persistensi arus kas, selain persistensi laba total, karena laba memiliki dua komponen, yakni akrual dan arus kas.

\section{DAFTAR PUSTAKA}

Atwood, T. J., M.S. Drake, dan L. A. Myers. 2010. Book-Tax Conformity, Earnings Persistence and The Association Between Earnings and Future Cash Flows. Journal of Accounting and Economics 50: 111-125.

Ayers, B. C., J. X. Jiang, dan P. E. Yeung. 2006. Discretionary Accruals and Earnings Management: An Analysis of Pseudo Earnings Targets. The Accounting Review 81 (3): 617-652.

Ayers, B. C., J. X. Jiang, dan S.K. Laplante. 2008. Taxable Income as a Performance Measure: The Effects of Tax Planning and Earnings Quality. Contemporary Accounting Research 26 (1).http://ssrn. com/abstract $=930406$. Diakses tanggal 8 Maret 2012.

Balakrishnan, K., J. Blouin, dan W. Guay. 2011. Does Tax Aggressiveness Reduce Financial Reporting Transparency? http://ssrn.com/abstract $=1792783$. Diakses tanggal 8 Maret 2012).

Bartov, E., D. Givoly, dan C. Hayn. 2002. The Reward to Meeting or Beating Earnings Expectations. Journal of Accounting and Economics 33 (2): 173204.

Bhattacharya, U., H. Daouk., dan M. Welker. 2003. The World Price of Earnings Opacity. The Accounting Review 78 (3): 641-678. 
Beaver, W.H. 2002. Perspectives on Recent Capital Market Research. The Accounting Review 77(2): 453-474.

Chen, L.H., D.S. Dhaliwal, dan M.A. Trombley. 2007. The Impact of Earnings Management and Tax Planning on The Information Content of Earnings. http://ssrn.com/abstract $=1028808$. Diakses tanggal 8 Maret 2012.

Cohen, D.A. dan P. Zarowin. 2008. Economic Consequences of Real and AccrualBased Earnings Management Activities. jindal.utdallas.edu/files/Zarowin.pdf. Diakses tanggal 8 Maret 2012. 2010. Accrual-based and Real Earnings Management Activities around Seasoned Equity Offerings. Journal of Accounting and Economics 50: 2-19.

Darussalam dan D. Septriadi. 2009. Tax Avoidance, Tax Planning, Tax Evasion, dan Anti Avoidance Rule. http://www. ortax.org/ortax $/$ mod $=$ issueEpage $=$ showE $i$ $d=36 \mathcal{E} q=\mathcal{E} h l m=2$. Diakses tanggal 8 Oktober 2012.

Faiz, D. 2011. Manfaat Perencanaan Pajak (Tax Planning). http://blogpejantantang gung.blogspot.com/2011/05/manfaatperencanaan-pajak-tax-planning.html. Diakses tanggal 3 Juni 2012.

Graham, J.R., C.R. Harvey, dan S. Rajgopal. 2005. The Economic Implications of Corporate Financial Reporting. http:// ssrn.com/abstract $=491627$. Diakses tanggal 10 September 2012.

Gunny, K. 2005. What Are the Consequences of Real Earnings Management? w4.stern.nyu.edu/.../docs/.../Gunny_paper. pdf. Diakses tanggal 10 September 2012. 2009. The Relation Between Earnings Management Using Real Activities Manipulation and Future Performance: Evidence From Meeting Earnings Benchmarks. http://ssrn.com/abstract=816025Diakses tanggal 10 September 2012.

Hanlon, M. 2005. The Persistence and Pricing of Earnings, Accruals and Cash Flows When Firm Have Large Book-
Tax Differences. The Accounting Review 80 (1): 137-166.

Hanlon, M. dan T. Shevlin. 2005. Book-Tax Conformity for Corporate Income: An Introduction to The Issues. www.nber.org/chapters/c0166.pdf.

Diakses tanggal 15 Maret 2012.

Hanlon, M., E.L. Maydew, dan T. Shevlin. 2006. Book-Tax Conformity and The Information Content of Earnings. http://ssrn.com/abstract=881561. Diakses tanggal 15 Maret 2012).

2007. An Unintended

Consequence of Book-Tax Conformity: A Loss of Earnings Informativeness. http://ssrn.com/abstract=1280509. Diakses tanggal 15 Maret 2012.

Healy, P.M. 1985. The Effects of Bonus Schemes on Accounting Decisions. Journal of Accounting and Economics 7: 85-107.

Healy, P.M. dan K.G. Palepu, 1995. The Challenges of Investor Communication: The Case of CUC International, Inc. Journal of Financial Economics 38: 111140.

Hutami, S. 2012. Tax Planning (Tax Avoidance Dan Tax Evasion) Dilihat dari Teori Etika.

ejournal.politama.ac.id/index.php/politekno sains/article/.../25/22. Diakses tanggal 6 Oktober 2012).

Ibrahim, S., L. Xu, dan G. Rogers. 2011. Real and Accrual-Based Earnings Management and Its Legal Consequences: Evidence From Seasoned Equity Offerings.

http://www.emeraldinsight.com/journals.ht $m$ ? articleid $=1941454$. Diakses tanggal 10 September 2012.

Jonas, G.J. dan J. Blanchet. 2000. Assessing Quality of Financial Reporting. Accounting Horizons 14 (3): 353-363.

Kothari, S.P.; A.J. Leone, dan C.E. Wasley. 2005. Performance Matched Discretionary Accrual Measures. Journal of Accounting and Economics 39: 163-197.

Klijnveld, Peat, Marwick, Goerdeler (KPMG). 2007. The Governance of Tax: 
A Discussion Paper. www.audit-commit tee-institute.be/dbfetch/... Diakses tanggal 26 Desember 2012.

Lee, N. dan C. Swenson. 2011. Earnings Management through Discretionary Expenditures in The U.S., Canada, and Asia. International Business Research 4 (2): 257-266.

Mathari, R., R. Amelia, dan R. Prakoso. 2010. Empat Kasus Pajak Besar: Grup Bakrie.

http://www.beritasatu.com/mobile/ekonomi 10707-empat-kasus-pajakbesar-grupbakrie.html. Diakses tanggal 4 Juni 2012.

McGuire, S. T., S. S. Neuman, dan T.C. Omer. 2012. Sustainable Tax Strategies and Earnings Persistence.

http://ssrn.com/abstract=1950378. Diakses tanggal 21 Desember 2012.

Penman, S. H. dan X. J. Zhang. 1999. Accounting Conservatism, the Quality of Earnings, and Stock Returns.

http://papers.ssrn.com/sol3/papers.cfm?abs tract_id=201048.Diakses tanggal 9 Oktober 2012.

Ratmono, D. 2010. Manajemen Laba Riil dan Berbasis Akrual: Dapatkah Auditor yang Berkualitas Mendeteksinya? Prosiding Simposium Nasional Akuntansi XIII Purwokerto.

Roubi, R. R. dan A. W. Richardson. 1998. Managing Discretionary Accruals in Response to Reductions in Corporate Tax Rates in Canada, Malaysia, and Singapore. The International Journal of Accounting 33 (4): 455-467.

Roychowdhury, S. 2006. Earnings Management through Real Activities Manipulation. $h$ ttp://ssrn.com/abstract $=477941$ (diakses tanggal 11 Februari 2012).

Scott, W. R. 2009. Financial Accounting Theory, Fifth Edition. Pearson Prentice Hall. Canada.

Setyowati, L. 2002. Rekayasa Akrual untuk Meminimalkan Pajak.Jurnal Riset Akuntansi Indonesia 5 (3): 325-340.

Siregar, S. V. N. P. dan S. Utama. 2006. Pengaruh Struktur Kepemilikan, Ukuran Perusahaan, dan Praktek Corporate
Governance terhadap Pengelolaan Laba (Earnings Management). Jurnal Riset Akuntansi Indonesia. 9(3): 307-326.

Sloan, R. G. 1996. Do Stock Prices Fully Reflect Information in Accruals and Cash Flows About Future Earnings? The Accounting Review 71 (3): 289-315.

Suandy, E. 2006. Perencanaan Pajak, Edisi 3. Salemba Empat. Jakarta.

Subagyo dan Oktavia. 2010. Manajemen Laba Sebagai Respon Atas Perubahan Tarif Pajak Penghasilan Badan di Indonesia. Prosiding Simposium Nasional Akuntansi XIII Purwokerto.

Subekti, I., A. Wijayanti, dan K. Akhmad. 2010. The Real and Accruals Earnings Management: Satu Perspektif dari Teori Prospek. Prosiding Simposium Nasional Akuntansi XIII Purwokerto.

Subramanyam, K. R. 1996. The Pricing of Discretionary Accruals. Journal of Accounting and Economics 22(1-3): 249281.

Sunarto. 2009. Teori Keagenan dan Manajemen Laba.Kajian Akuntansi 1 (1): 13-28.

2010. Peran Persistensi Laba terhadap Hubungan Antara Keagresifan Laba dan Biaya Ekuitas. Kajian Akuntansi 2(1): 22-38

Taylor, G. K. dan R. Z. Xu. 2008. Consequences of Real Earnings Management on Subsequent Operating Performance. Research in Accounting Regulation 22: 128-132.

Tinto, R. 2011. Our Tax Strategy and Governance.

http://www.riotinto.com/ourapproach/ 21725_our_tax_strategy_and_governance. asp. Diakses tanggal 26 Desember 2012.

Watts, R. L. dan J. L. Zimmerman. 1986. Positive Accounting Theory. Prentice Hall, Inc., Englewood Cliffs. New Jersey.

Weisbach, M.S. 1988. Outside Directors and CEO Turnover. Journal of Financial Economics 20: 431-460.

Wijaya, M. dan D. Martani. 2011. Praktik Manajemen Laba Perusahaan dalam Menanggapi Penurunan Tarif Pajak 
Sesuai UU No. 36 Tahun 2008. Prosiding Simposium Nasional Akuntansi XIV Aceh. Wijayanti, H. T. 2006.Analisis Pengaruh Perbedaan Antara Laba Akuntansi dan Laba Fiskal terhadap Persistensi Laba, Akrual, dan Arus Kas. Prosiding Simposium Nasional Akuntansi IX Padang.

Wild, J. J., K. R. Subramanyam, dan R.F. Halsey. 2005. Financial Statement Analysis. Bachtiar, Y.S. dan S.N. Harahap (penerjemah). Analisis Laporan Keuangan. Edisi 8. Salemba Empat. Jakarta.

Wulandari, D., Kumalahadi, dan J.E. Prasetyo. 2004. Indikasi Manajemen Laba Menjelang Undang-Undang Perpajakan 2000 pada Perusahaan Manufaktur yang Terdaftar di Bursa Efek Jakarta. Prosiding Simposium Nasional Akuntansi VII Denpasar.
Yamashita, H. dan K. Otogawa. 2007. Do Japanese Firms Manage Earnings in Response to Tax Rate Reduction in the Late 1990s? www.ms.kuki.tus.ac.jp/ shelf/MS-0701.pdf. Diakses tanggal 8 Maret 2012.

$\mathrm{Yu}$, W. 2008. Accounting-Based Earnings Management and Real Activities Mani pulation. Disertasi. Doctor of Philosophy in the School of Management. Georgia Institute of Technology.

Zang, A. Y. 2006. Evidence on The Trade-off Between Real Activities Manipulation and Accrual-based Earnings Management. http://ssrn.com/abstract $=1891759$. Diakses tanggal 10 September 2012. 